\title{
Generalized expected utility, heteroscedastic error, and path dependence in risky choice
}

\author{
David Buschena • David Zilberman
}

Published online: 27 February 2008

(C) Springer Science + Business Media, LLC 2008

\section{Erratum to: J Risk Uncertainty DOI 10.1023/A:1007814719863}

Due to a programming error, there were numerical errors in the article "Generalized Expected Utility, Heteroscedastic Error, and Path Dependence in Risky Choice" by David Buschena and David Zilberman, which appeared on pp. 67-88 of Volume 20, Number 1 of the Journal of Risk and Uncertainty. Some of these errors also affect the interpretation of the results. The author has posted corrections to this paper at http://www.montana.edu/econ/buschena/jruerratapaper112007.pdf.

The online version of the original article can be found at http://dx.doi.org/10.1023/A:1007814719863.

D. Buschena $(\bowtie)$

Department of Agricultural Economics and Economics, Montana State University,

306 Linfield Hall, Bozeman, MT 59717, USA

e-mail: buschena@montana.edu

D. Zilberman

Department of Agricultural and Resource Economics and Policy, University of California, 207 Giannini Hall, Berkeley, CA 94720, USA 